\title{
Minimum tillage could benefit California rice farmers
}

\author{
by Bruce Linquist, Albert Fischer, Larry Godfrey, \\ Chris Greer, James Hill, Kaden Koffler, Michael \\ Moeching, Randal Mutters and Chris van Kessel
}

Field research and grower interviews were used to evaluate the potential of minimum tillage for California rice systems. We found that by tilling only in the fall (instead of both the fall and spring), rice farmers can control herbicide-resistant weeds when combined with a stale rice seedbed, which entails spring flooding to germinate weeds followed by a glyphosate application to kill them. Our results indicated that yield potentials are comparable between waterseeded minimum- and conventionaltill systems. We also found that rice growers can reduce fuel costs and plant early. However, minimum tillage may require more nitrogen fertilizer to achieve these yields.

$\mathrm{R}$ ice is produced on about 500,000 acres in the Sacramento Valley annually, making it the region's major crop. Rice is a cereal crop that has been grown in California since the early 1900s. It is grown in flooded soils, so it is ideally suited to the poorly drained soils common to much of the Sacramento Valley.

Most rice growers till both in the fall to incorporate rice straw and in the spring to prepare the seedbed. Typical spring tillage involves six to eight tractor passes that include chisel plowing, disking and planing before applying fertilizer, and rolling the field in preparation for planting. No-till rice systems are not likely to be successful in California because harvesting equipment can leave deep tracks in the field that results in poor rice establishment and weed problems. Fall tillage is necessary to level the field and incorporate rice straw, but minimum-till rice systems with no spring tillage may be an option.

Minimum-till systems are not new to rice and are being evaluated in the

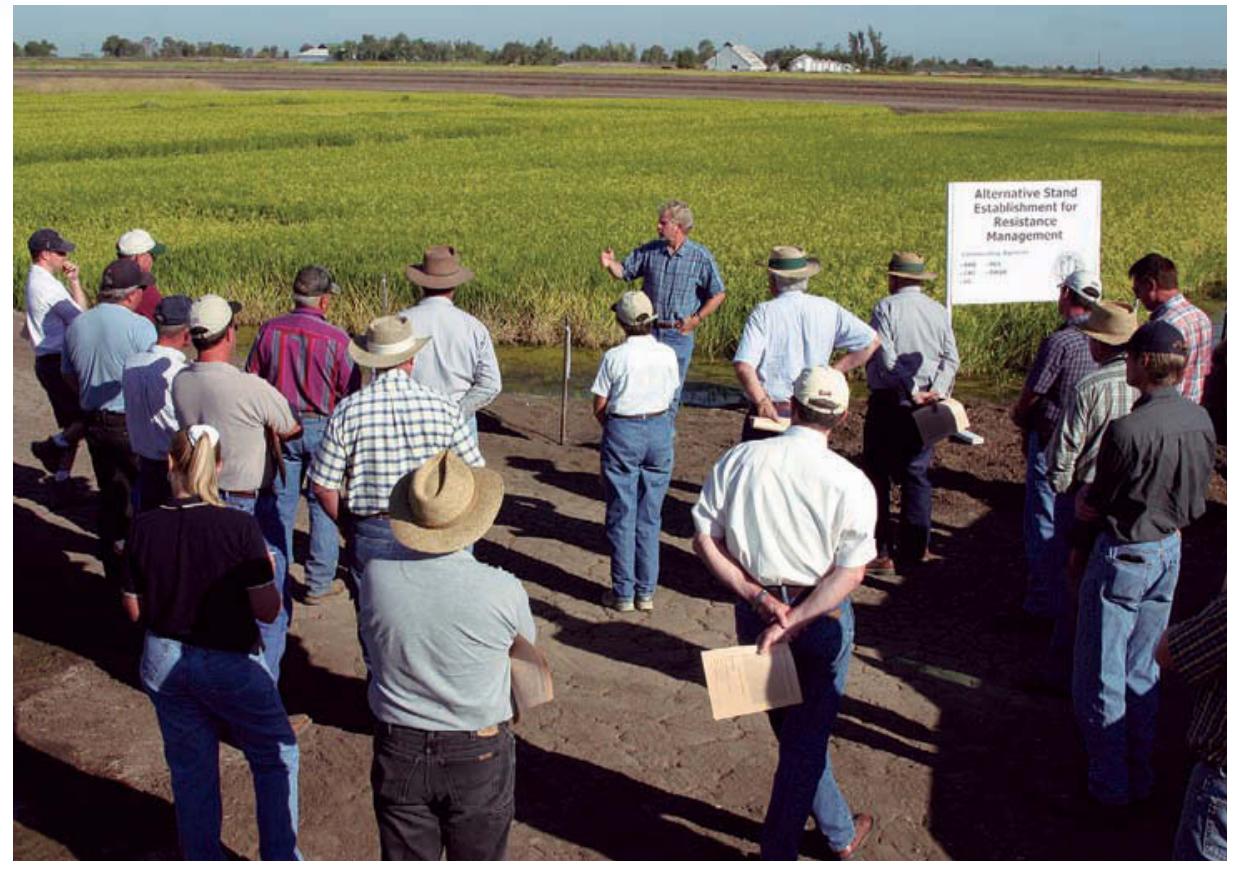

Butte County extension advisor Randal Mutters explains the differences in rice establishment systems to farmers at a field day at the California Rice Experiment Station.

southern United States (Watkins et al. 2004) and Asia (Lal et al. 2004). In these areas, rice is grown in rotation with other crops such as soybean and wheat, respectively. In contrast, most California rice systems do not involve crop rotations due to the heavy soils on which they are grown. Nevertheless, there is increasing interest in growing rice in California with no spring tillage due to the potential for reduced fuel costs, earlier planting (which allows an earlier harvest, in turn helping ensure that fall rains do not interrupt operations), better control of herbicide-resistant weeds, and potential air-quality improvements due to reduced dust.

Herbicide-resistant weeds are one of the main problems threatening the long-term sustainability of California's rice-based systems. In fact, California rice has seven herbicide-resistant weed species, more than any other crop or geographic area in the United States (Heap 2007). Herbicide resistance has evolved in rice weed populations due to repeated use of the same herbicide, her- bicides having the same mode of action, or herbicides detoxified by a common mechanism in plants and weeds.

Minimum tillage with a stale seedbed offers new opportunities to control herbicide-resistant weeds in California rice fields. The approach entails preparing a stale seedbed before planting by flushing or flooding the field with water to induce weed-seed germination, and then killing the weeds, usually with glyphosate. The choice between flushing or flooding depends on whether or not the field is infested with weeds that require water saturation to germinate. The soil is then left untilled to ensure that buried weed seeds are not brought to the surface to germinate. This combination of a stale seedbed and no spring tillage can currently control all types of herbicide-resistant weeds in California rice systems, because they are not resistant to glyphosate.

\section{Minimum versus conventional till}

An experiment was initiated in 2004 at the California Rice Experiment 


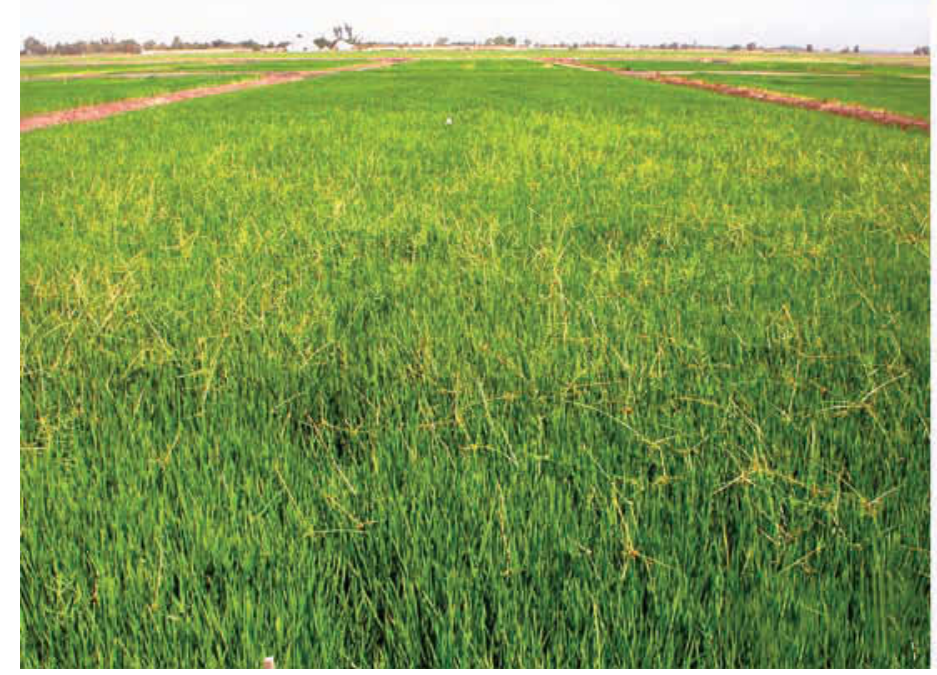

In the absence of herbicides or a stale seedbed treatment, weeds such as smallflower umbrella sedge were a problem in the conventional system studied.

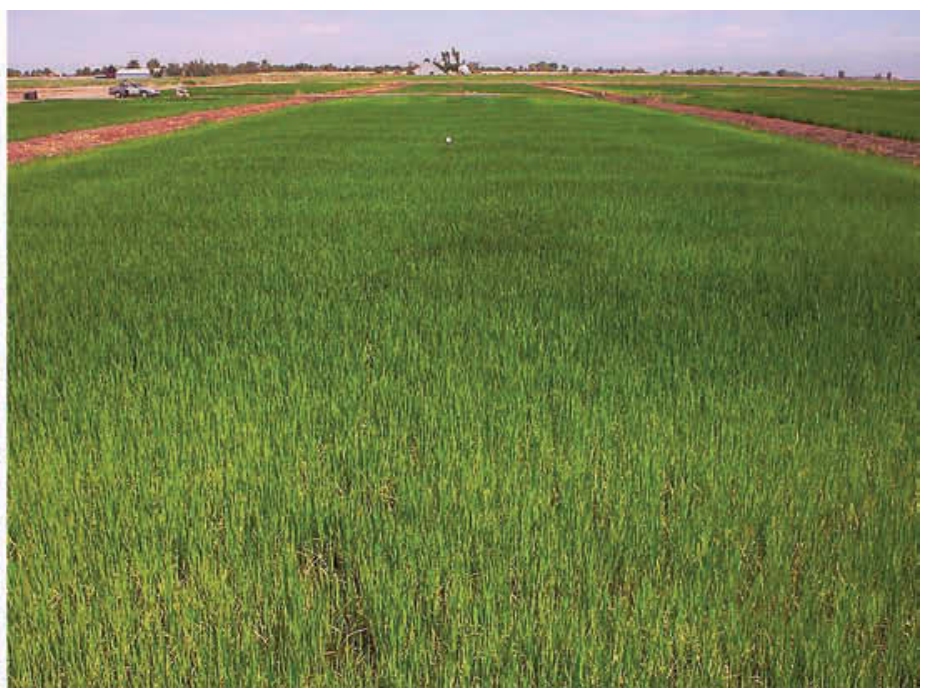

A stale seedbed treatment followed by a glyphosate application effectively controlled weeds in the minimum-till treatment; no other herbicides were necessary here in 2004.
Station (RES) near Biggs in Butte County, to evaluate crop establishment methods and their effects on rice yield, weed and pest populations, and nitrogen cycling. The experiment was set up as a randomized complete block design with four replications on 0.5 -acre plots. In this paper we discuss two treatments: water-seeded conventional till and water-seeded minimum till with a stale seedbed. Water-seeding refers to broadcasting rice seed into a flooded field, a practice used by more than $90 \%$ of California rice growers.

In both treatments, the plots were tilled in the fall to incorporate rice straw and then flooded to encourage straw decomposition. The conventional-till treatment replicated the practice of most California rice growers, and entailed spring tillage (chisel, disk, roll), flooding and planting. The minimum-till treatment had no spring tillage but the plots were flushed with water to prepare a stale seedbed prior to planting. Both the conventional- and minimumtill plots were flooded and planted (broadcasting 150 pounds of rice seed per acre into the flood water) on the same day. The plots remained flooded until a few weeks before harvest.

Weed control. In the minimum-till treatment a stale seedbed was prepared, which entailed flushing the plots with water in April and then draining. After the weeds germinated, glyphosate was applied at a rate of 1.2 pounds acid equivalent per acre. Other than this, weeds in both tillage treatments were managed similarly during the growing season with the objective of obtaining full control. This was accomplished using propanil (6 pounds active ingredient per acre) and penoxsulam (1.2 ounces active ingredient per acre) applied at the four- to five-leaf stage of rice. This mixture of broad-spectrum herbicides with different modes of action is the currently recommended practice for managing herbicide-resistant weeds.

A 3,000-square-foot portion of each plot was left untreated to monitor weed recruitment and evaluate the effectiveness of the stale seedbed. In the minimum-till treatment, this area received glyphosate prior to planting but not the other herbicides used in the

\section{California rice has seven herbicide-resistant} weed species, more than any other crop or geographic area in the United States.

rest of the plot. In the conventional-till treatment, this area did not receive any herbicides. The number of weeds per square foot in these areas was determined from 10 randomly placed, square-foot quadrats in each plot at approximately the time of rice canopy closure (20 to 30 days after planting).

Pests. Rice water weevil is the most important invertebrate pest of California rice. The larvae feed on rice plant roots and cause crop damage, but the severity of weevil infestations can be monitored based on the degree of leaf scarring by the leaf-eating adults. Adult weevil feeding was monitored from the three-to-five rice leaf stage. Larvae were counted twice ( 2 weeks apart) in 10 soil samples in all plots in July.

Fertilizer management. Fertilizer management varied between the two study treatments due to differences in water management and tillage. Phosphorus and potassium fertilizer were applied on all plots prior to permanent flooding. In the conventional tillage plots the phosphorus and potassium were tilled into the soil with the tillage operations, but in the minimumtill system it remained on the surface.

Nitrogen fertilizer (as urea) was applied at a rate of 150 pounds per acre, within the recommended range for rice (UCCE 2006). In the conventionaltill system, the field remained permanently flooded and anaerobic, and all of the nitrogen was applied in a single dose incorporated 3 to 4 inches below the soil surface prior to planting. In the minimum-till system, since the soil was left undisturbed following the stale seedbed treatment, nitrogen fertilizer was applied on the soil surface instead of below it. Two-thirds of the nitrogen was broadcast on the surface just before flooding for planting, and the remaining third was broadcast between 40 and 50 days after planting.

Nitrogen fertility trial. To determine the most efficient nitrogen manage- 
TABLE 1. Nitrogen rates, timing and yields (adjusted to $14 \%$ moisture) for conventional- and minimum-till treatments at Rice Experiment Station, 2004 and 2006

\begin{tabular}{|c|c|c|c|c|c|c|c|c|c|}
\hline \multirow[b]{2}{*}{ Tillage system* } & \multicolumn{5}{|c|}{2004} & \multicolumn{4}{|c|}{2006} \\
\hline & Total nitrogen applied & Preflusht & Preplant & Top-dress PI¥ & Yield & Total nitrogen applied & Preplant & Top-dress PIt & Yield \\
\hline & & $\cdots / b \mathrm{~N} / \mathrm{a}$ & 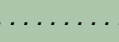 & $\cdots \cdots$ & Ib/ac & $\ldots \ldots \ldots \ldots \cdots \cdot \mid b$ & V/ac... & $\ldots \ldots \ldots \ldots$ & Ib/ac \\
\hline \multirow[t]{5}{*}{ Conventional } & 0 & NA§ & 0 & 0 & $6,295 b$ & 0 & 0 & 0 & $4,057 b$ \\
\hline & 50 & NA & 50 & 0 & $8,308 a$ & 100 & 100 & 0 & $9,081 a$ \\
\hline & 100 & NA & 100 & 0 & $8,269 a$ & 100 & 50 & 50 & $8,678 a$ \\
\hline & 150 & NA & 150 & 0 & $8,097 a$ & 150 & 150 & 0 & $8,960 a$ \\
\hline & 200 & NA & 200 & 0 & $8,673 a$ & 200 & 200 & 0 & $9,405 a$ \\
\hline \multirow[t]{5}{*}{ Minimum } & 0 & 0 & 0 & 0 & $3,539 c$ & 0 & 0 & 0 & $3,556 c$ \\
\hline & 100 & 0 & 50 & 50 & $7,085 b$ & 100 & 100 & 0 & $8,663 a b$ \\
\hline & 150 & 0 & 100 & 50 & $8,432 a b$ & 100 & 50 & 50 & $7,306 b$ \\
\hline & 150 & 50 & 50 & 50 & $9,178 a$ & 150 & 100 & 50 & $9,728 a$ \\
\hline & 150 & 50 & 100 & 0 & $8,305 a b$ & 200 & 200 & 0 & $10,110 a$ \\
\hline $\begin{array}{l}\text { * In conventional ti } \\
\text { Yield means withi } \\
\text { † Nitrogen fertilizer } \\
\text { ‡ } \mathrm{PI}=\text { nitrogen ferti } \\
\text { § } \mathrm{NA}=\text { not applicab }\end{array}$ & $\begin{array}{l}\text { all nitrogen fertilizer was inc } \\
\text { the same system and year, fol } \\
\text { applied before flush for stale s } \\
\text { zer top-dressed between mid- } \\
\text {. }\end{array}$ & $\begin{array}{l}\text { rporated; in } n \\
\text { owed by the s } \\
\text { eedbed treatn } \\
\text { illering and } p\end{array}$ & $\begin{array}{l}\text { nimum till, pr } \\
\text { ne letter, are } \\
\text { nt. } \\
\text { icle initiation }\end{array}$ & $\begin{array}{l}\text { plant nitrogen wa } \\
\text { lot significantly di }\end{array}$ & $\begin{array}{l}\text { applied on } \\
\text { erent (LSD } 0\end{array}$ & $\begin{array}{l}\text { e surface. } \\
5 \text { ). }\end{array}$ & & & \\
\hline
\end{tabular}

\begin{tabular}{|c|c|c|c|c|}
\hline $\begin{array}{l}\text { Tillage } \\
\text { system }\end{array}$ & 2004 & 2005 & 2006 & Mean \\
\hline \multicolumn{5}{|c|}{...... Ib/ac (14\% moisture).....} \\
\hline Conventional & 9,511 & 7,295 & 7,923 & 8,243 \\
\hline Minimum & 9,303 & 7,299 & 7,457 & 8,020 \\
\hline ANOVA & ns & ns & ns & ns \\
\hline
\end{tabular}

ment practices for each tillage system, a nitrogen fertility trial was conducted in 2004 and 2006. This trial included five 400-square-foot subplots within each plot (minimum and conventional tillage) to which no nitrogen fertilizer had previously been applied. The location of these subplots within the main plots changed each year to avoid the compounding effects of the nitrogen fertility treatments. Nitrogen fertilizer rates ranged from 0 to 200 pounds per acre in the subplots (table 1). In the conventional-till treatment, nitrogen was always applied as a single dose (with the exception of one treatment in 2006) and incorporated below the soil surface before flooding for planting. In the minimum-till treatment, nitrogen was applied either as a single dose or split between two doses.

Data analysis. All data were analyzed using Statistical Analysis System (SAS version 9.1) software. Main plot yields, weed data and water weevil data were analyzed using a randomized complete block design. The nitrogen fertility trial was analyzed using a split-plot design.
Grower interviews. In 2006, late rains prevented many growers from normal spring tillage operations and a few growers were faced with the option of no spring tillage, and planting late or not planting at all. In winter 2007, we did phone interviews with three growers who did not use spring tillage in 2006 - as many as we could find. The purpose was to compare results from our relatively small experimental plots with what growers found at the field scale. Growers were asked to compare their minimum-till field with an adjacent conventional field, and to answer questions about productivity, tillage practices, and weed and fertilizer management. Growers were also asked how they would improve the minimum-till system and if they thought it was economical.

\section{Minimum tillage compares well}

Similar rice yields. Yields in the minimum-till treatment were similar to the conventional-till treatment in all years. The highest yield was more than 9,300 pounds per acre in 2004, and the lowest was about 7,300 pounds per acre in 2005 (table 2). These annual yield fluctuations are in line with countywide fluctuations in California and reflect climate variation.

Better weed control. The minimumtill treatment was extremely effective in depleting weed populations from the upper soil layer and markedly diminishing weed emergence with the crop (table 3). When this practice was used, little weed control was needed after the glyphosate application. In fact, no additional herbicides were needed in 2004.

The most important rice weed in these systems during the study period was smallflower umbrella sedge (Cyperus difformis). On average for the 3 years, the minimum-till treatment suppressed smallflower umbrella sedge populations by $94 \%$. Infestations by the aquatic ricefield bulrush (Schoenoplectus mucronatus) also became relevant $(P<$ 0.05 ) in 2006, and were $91 \%$ suppressed under the minimum-till treatment (table 3). Water-seeding rice strongly suppressed both barnyardgrass (Echinochloa crus-galli), the main Echinochloa species in this field (there was also some early watergrass), and sprangletop (Leptochloa fascicularis) (data not shown). However, Echinochloa spp. populations became somewhat higher in the last year of the experiment, and the minimum-till treatment also exhibited potential for suppressing this weed.

Success with the stale seedbed technique depends on keeping the seedbed moist or highly saturated, depending on if aquatic weeds are present, and allowing sufficient time for weeds to emerge prior to the glyphosate application. In 2006, there was neither sufficient seedbed moisture nor sufficient time for substantial weed emergence. Consequently, few weeds were present when the glyphosate was applied. Even so, the minimum-till treatment was successful in controlling weeds, suggesting that leaving the soil undis- 


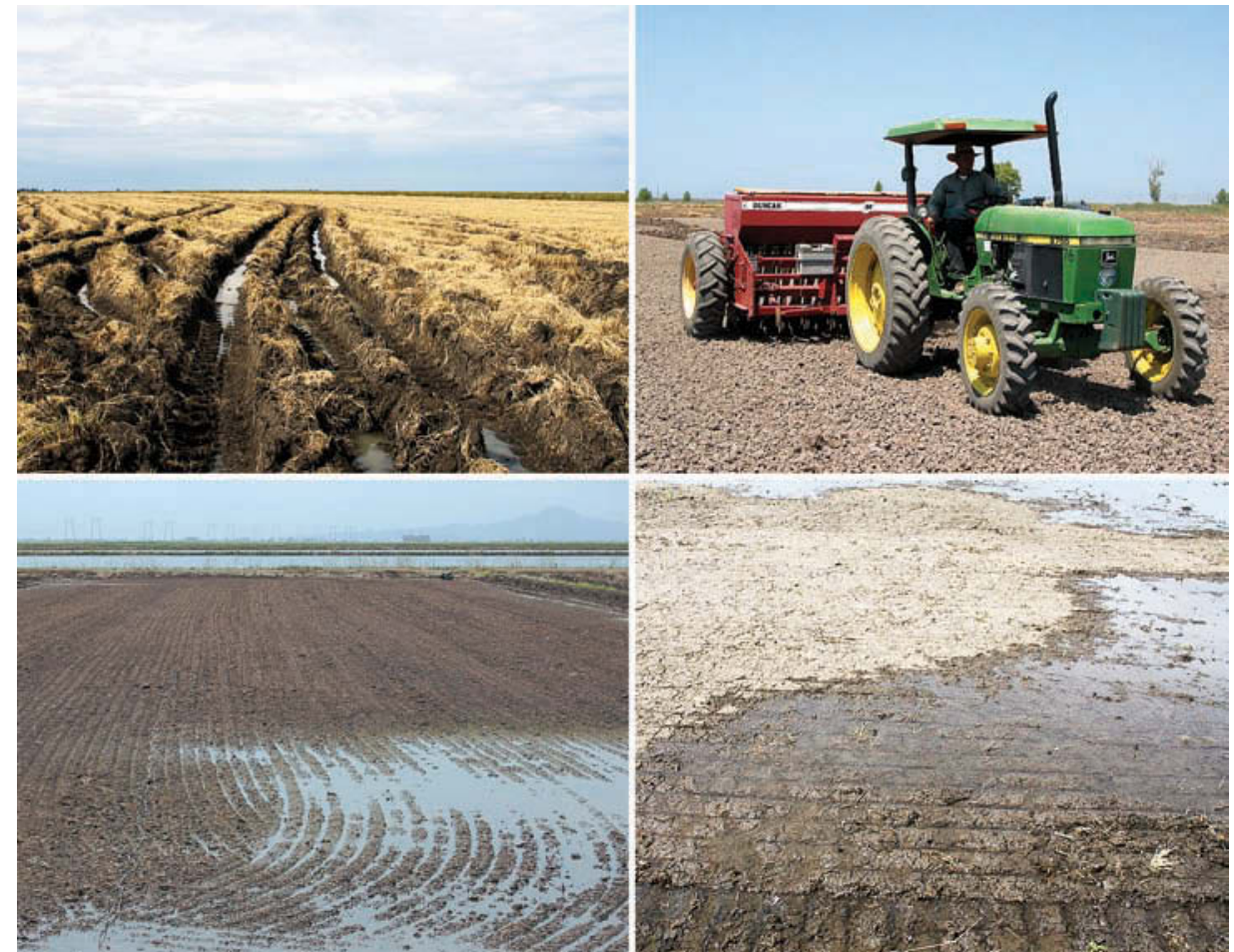

Top left, complete no-till is unlikely to succeed due to heavy rutting during the rice harvest and the need to decompose rice straw. Top right, nitrogen fertilizer is applied to the main plot in the conventional water-seeded system. Bottom right, water moves across the minimum-till treatment prior to planting; the soil surface is firm, with grooves made by a roller. Notice the difference in soil conditions between minimum tillage and, bottom left, conventionally managed rice fields.

turbed in the spring helped discourage weed emergence.

While the stale seedbed technique worked well when enough weeds had emerged prior to the glyphosate application, the late-emerging aquatic weeds ducksalad (Heteranthera limosa) and redstem/redberry (Ammannia spp.) were not well suppressed (table 3 ); in fact, ducksalad became an increasing problem over time in the minimum-till treatment.

Similar rice water weevil levels. There were no differences in rice water weevil levels between the conventional- and the minimum-till treatments in a given year, although there was a trend toward more weevils with minimum tillage. The weevils were present at low levels in all plots in 2005 and 2006. The incidence of adult feeding scars was higher in 2005 than 2006, with $15 \%$ and $7 \%$ of plants scarred, respectively. Likewise, larval densities, which peaked at 0.2 per

sample in 2006, did not differ between the two treatments in any given year.

\section{Nitrogen management differs}

When no nitrogen fertilizer was applied, the minimum-till treatment had smaller yields than conventional tillage (table 1). This is probably because minimum tillage had two flooding events while conventional tillage had only one. When soil is flooded and then drained, nitrate accumulates during the aerobic period but may be subsequently lost through denitrification during the following anaerobic period (Patrick and Wyatt 1964; Linquist et al. 2006). In response to added fertilizer, the results varied between years but suggested that minimum tillage requires more nitrogen than conventional tillage to reach similar yields. In 2004, the minimum-till treatment required three times as much nitrogen as the conventional-till treatment to achieve optimal yields (150 versus 50 pounds of nitrogen per acre, respectively). In contrast, in 2006 similar nitrogen rates in the two till systems resulted in similar yields.

Splitting the nitrogen fertilizer dose has previously been shown to increase its use efficiency (Broadbent and Mikkelsen 1968; Linquist and Sengxua 2003). However, that was not the case in the nitrogen fertility trial portion of this study. Splitting the 150 pounds of nitrogen per acre in 2004 did not affect yields. This may be because this nitrogen rate exceeded that required for optimal yields, masking any increases in use efficiency. Splitting the 100 pounds of nitrogen per acre equally in 2006 actually resulted in lower yields than a single application of this rate at planting. However, it is possible that higher yields would have resulted from an unequal split, such as 75 pounds of nitrogen per acre at planting and 25 pounds per acre 40 to 50 days after planting.

The nitrogen fertility experiments were not conclusive, and further research is warranted. However, some general conclusions can be drawn based on our results. First, the additional flush of water in the minimum-till system will likely result in the loss of native 


\begin{tabular}{|c|c|c|c|}
\hline Operation & Grower 1 & Grower 2 & Grower 3 \\
\hline County & Colusa & Glenn & Colusa \\
\hline $\begin{array}{l}\text { Straw and winter } \\
\text { flood }\end{array}$ & Baled/tilled/unflooded & $\begin{array}{l}\text { Chopped/flooded/ } \\
\text { stomped }\end{array}$ & Incorporated/flooded \\
\hline Stale seedbed & Yes & Yes & No \\
\hline Planting date & April 26 & May 3 & May 2 \\
\hline Variety & M401 & M401 & M202 \\
\hline Seeding rate & $20 \mathrm{lb} / \mathrm{ac}$ more & Same & $25 \mathrm{lb} / \mathrm{ac}$ more \\
\hline Yield & $7,100 \mathrm{lb} / \mathrm{ac}$ & $9,000 \mathrm{lb} / \mathrm{ac}$ & $7,600 \mathrm{lb} / \mathrm{ac}$ \\
\hline $\begin{array}{l}\text { Yield relative to } \\
\text { other fields }\end{array}$ & Similar & Similar or better & Less by $600 \mathrm{lb} / \mathrm{ac}$ \\
\hline Main weed species & $\begin{array}{l}\text { Sprangletop/redberry/ } \\
\text { watergrass/SFU* }\end{array}$ & Watergrass/SFU & $\begin{array}{l}\text { Watergrass/sprangletop/ } \\
\text { SFU/redberry }\end{array}$ \\
\hline Weed species & Same & Same & Same \\
\hline Weed severity & Less & Same & Less \\
\hline Herbicide use & Lower rates & Different program & 1 less herbicide application \\
\hline Fertilizer & 4 top-dress & 3 top-dress & 3 top-dress \\
\hline Total nitrogen applied & $153 \mathrm{lb}$ N/ac & $140 \mathrm{lb}$ N/ac & $210 \mathrm{lb} \mathrm{N} / \mathrm{ac}$ \\
\hline Tractor passes & 6 less & 8 less & 7 less \\
\hline Air passes & 3 more & 4 more & 3 more \\
\hline Main problem & Fertility & Algae and ducks & Ducks \\
\hline $\begin{array}{l}\text { What would the } \\
\text { grower do differently? }\end{array}$ & $\begin{array}{l}\text { More fall land } \\
\text { preparation; improved } \\
\text { fertility management }\end{array}$ & $\begin{array}{l}\text { Incorporate straw } \\
\text { in fall and do more } \\
\text { tillage }\end{array}$ & $\begin{array}{l}\text { More fall land preparation } \\
\text { and put in field ditches for } \\
\text { better water management }\end{array}$ \\
\hline $\begin{array}{l}\text { Grower's economic } \\
\text { assessment }\end{array}$ & Better & Better & Same \\
\hline
\end{tabular}

soil nitrogen. Second, nitrogen fertilizer in the minimum-till system is applied to the soil surface, where it is used less efficiently (Mikkelsen and Finfrock 1957; Broadbent and Mikkelsen 1968). Both of these factors suggest that the minimum-till system will require a higher nitrogen rate to maintain yield levels. While we can not determine a precise rate from our data, it appears that minimum tillage requires approximately 50 pounds of nitrogen per acre more than conventional tillage. This is based on the 2004 response and the fact that in both years the zero nitrogen yields were lower in the minimum-till treatment, which suggests a loss of native soil nitrogen.

\section{Grower experiences}

Three growers were interviewed who established rice using waterseeded practices (aerially broadcasting seed into flood water) in 2006 onto fields where there had been no spring tillage (table 4). In all cases, the growers incorporated rice straw or stubble in fall 2005 either by disking or wet rolling. Winter flooding varied between the fields but due to a wet winter, all were flooded for at least a portion of the winter. Growers
1 and 2 used a modified stale seedbed in which late spring rains germinated weed seeds (as opposed to flushing with irrigation water) and glyphosate was used to kill the weeds before flooding the field to plant. Grower 3 aerially broadcast rice seed into water from the winter flood period and drained the field shortly after planting. In all cases, nitrogen was applied aerially in three to four applications. Total nitrogen was comparable to what each grower normally applied and ranged from 140 to 210 pounds per acre. was fertilizer management, specifically how and when to apply nitrogen and phosphorus. Results from the on-station (RES) study suggest that only one or two nitrogen fertilizer applications are necessary. Also, phosphorus should be applied in the fall and incorporated because surface phosphorus applications may result in an algae problem, which grower 2 experienced.

Despite the late spring rains, all before May 3 (most rice is planted from May 1 to June 15). These were the first planted fields in their respective areas, and as a result, growers reported some
One issue raised by the growers three growers were able to plant early, rice seed predation by ducks. While two of the three growers used slightly higher seeding rates than the recommended 150 pounds per acre, data from the on-station experiment suggests that this may not be necessary. Two of the three growers reported that yields from their minimum-till fields were comparable to or better than their other fields. However, grower 3 reported that yields were about 600 pounds less per acre. These lower yields may have been due to phosphorus deficiency since none had been applied, although this grower typically did apply phosphorus fertilizer. A second possibility for this lower yield is that rather than draining the field following the winter flood, grower 3 retained winter flood water until after planting, which may have lowered soil oxygen levels and resulted in poor crop establishment.

The predominant weed species found in the minimum-till fields were similar to those typically found by these growers (Echinochloa spp., sprangletop, smallflower umbrella sedge and redstem/redberry), and the severity of the weed problem was similar to or less than normal. The two growers using a stale seedbed reported that the rains germinated weeds, which they were able to kill with glyphosate. All growers reported that either lower rates of herbicides, fewer applications or a different program was used on their minimumtill fields. On-station research showed that the stale seedbed system was able to control much of the weed problem (table 3). However, research is needed to better understand how long soils should remain moist or flooded and what temperatures are required to germinate specific weed seeds.

\section{Benefits and drawbacks}

All three growers interviewed reported that the economic benefits of minimum tillage were similar to or better than their conventional-tillage practice, and some said they might try it again. The main reason was that minimum tillage resulted in six to eight fewer tractor passes, which amounts to a fuel and labor savings of $\$ 120$ per acre (Williams et al. 2001). However, some of these savings were offset by the ad- 

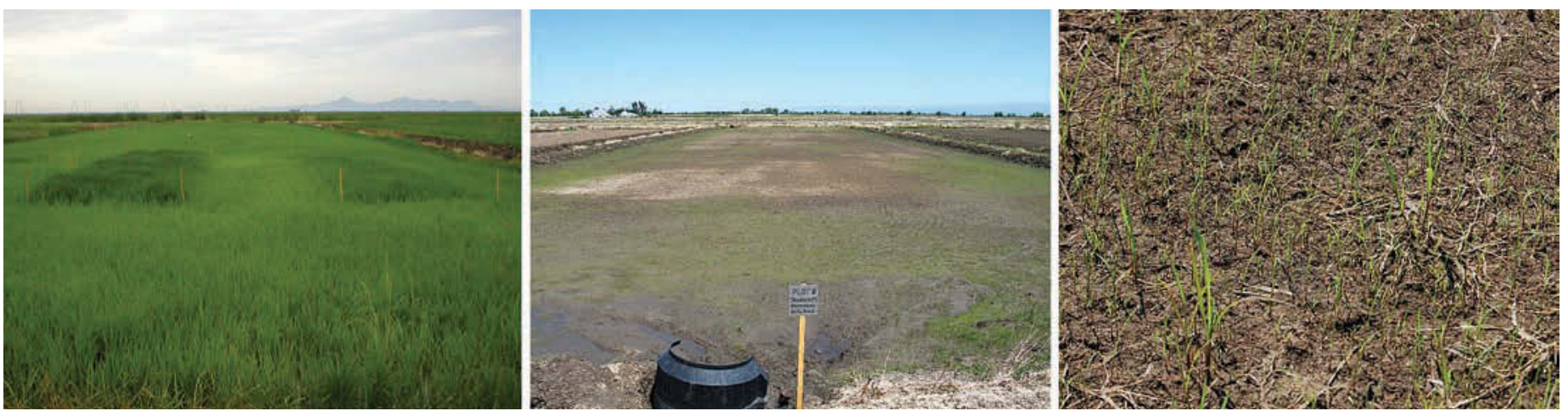

Left, within each of the main plots, nitrogen fertility plots were established to determine appropriate nitrogen rates and management strategies. Middle, a stale seedbed following a flush, with weeds beginning to emerge. Right, once the weeds have completely germinated they will be killed with a broad-spectrum herbicide.

ditional air passes required to apply glyphosate and fertilizer. Based on research from the on-station experiment, growers could apply fertilizer once or twice instead of the three to four times that they reported. Growers also indicated that if they were planning on no spring tillage, they would do more tillage in the fall, which would further offset the economic benefits. In addition to possible economic benefits, one major benefit was that growers were able to plant early despite late rains.

One drawback of the minimum-till system is the increased amount of nitrogen required to maintain yields. Since nitrogen must be applied on the surface, it is more susceptible to denitrification losses. This can have the effect of reducing the economy of these systems (urea nitrogen costs between 40 and 50 cents per pound) and increasing emissions of nitrous oxide, a greenhouse gas.

\section{Potential for minimum tillage}

In both on-station research and grower fields, the minimum-tillage system maintained rice yields in the absence of spring tillage. Where does minimum tillage fit in to a grower's overall farm-management strategy? First, minimum tillage can be useful when late spring rains prevent early planting under conventional tillage practices, as in 2006. Second, growers could employ minimum tillage to plant fields early. In such cases, additional tillage and phosphorus and potassium applications would be recommended in the fall.

Finally, minimum tillage can be used to control herbicide-resistant weeds by germinating weeds and subsequently killing them with glyphosate, an herbicide to which California's rice weeds are not yet resistant. Soil moisture must be carefully monitored and controlled because weed species require varying wet periods and temperatures for germination; this is an area of ongoing research. While glyphosate can currently control all types of California rice weeds that are resistant to other herbicides, glyphosateresistant weed biotypes have evolved in areas of California where this herbicide has been used for many years (Simarmata et al. 2003). Therefore, glyphosate should be alternated with other herbicides, such as paraquat and glufosinate-ammonium, that are also lethal to herbicide-resistant rice weeds (Fischer 2002).

\section{References}

Broadbent FE, Mikkelsen DS. 1968. Influence of placement on uptake and tagged nitrogen by rice. Agron J 60:674-7.

Fischer AJ. 2002. Managing watergrass (Echinochloa spp.) resistance to rice herbicides in an aquatic environment: Research and demonstration in affected farms. California Department of Pesticide Regulation, Final Report. Pest Management Grants-Applied Research Agreement \#00-0216S, March 1, 2002. www.cdpr.ca.gov/docs/pmap/ grants/00-01/finlrpts/00-0216S.pdf.

Heap I. 2007. The International Survey of Herbicide Resistant Weeds. www.weedscience.org/in.asp (accessed March 13, 2007).

Lal R, Hobbs PR, Uphoff N, Hansen DO (eds.). 2004. Sustainable Agriculture and the International Rice-Wheat System. New York: M Dekker. 532 p.

Linquist BA, Brouder SM, Hill JE. 2006. Winter straw and water management effects on soil nitrogen dynamics in California rice systems. Agron J 98:1050-9
B. Linquist is Project Scientist, and A. Fischer is Associate Professor, Department of Plant Sciences, UC Davis; L. Godfrey is Extension Specialist, Department of Entomology, UC Davis; C. Greer is UC Cooperative Extension (UCCE) Farm Advisor, Sutter County; J. Hill is Rice Specialist, UC Davis; K. Koffler is Ph.D. Student, Department of Plant Sciences, UC Davis; M. Moeching was Postdoctoral Researcher, UC Davis, and currently is Extension Specialist, University South Dakota; R. Mutters is UCCE Farm Advisor, Butte County; and C. van Kessel is Chair, Department of Plant Sciences, UC Davis. CalFed, the California Rice Research Board, the U.S. Department of Agriculture and the UC Statewide IPM program funded this research. The Rice Experiment Station provided land, access to facilities and equipment, and technical assistance and support. We greatly appreciate the equipment loaned by grower John Thompson. Steve Bickley, Jim Eckert and Ray Wennig were responsible for much of the day-to-day management of the on-station research.
Linquist BA, Sengxua P. 2003. Efficient and flexible management of nitrogen for rainfed lowland rice. Nutr Cycl Agroecosys 67:107-15.

Mikkelsen DS, Finfrock DC. 1957. Availability of ammoniacal nitrogen to lowland rice as influenced by fertilizer placement. Agron J 49:296-300.

Patrick WMH Jr, Wyatt R. 1964. Soil nitrogen loss as a result of alternate submergence and drying. Soil Sci Soc Proc 29:647-53.

Simarmata M, Kaufmann JE, Penner D. 2003. Potential basis of glyphosate resistance in California rigid ryegrass (Lolium rigidum). Weed Sci 51:678-82.

[UCCE] University of California Cooperative Extension and Rice Research Board. 2006. Rice Production Workshop 2006.

Watkins KB, Anders MM, Windham TE. 2004. An economic comparison of alternative rice production systems in Arkansas. J Sust Ag 24(4):57-78.

Williams JF, Mutters RG, Klonsky KM, De Moura RL. 2001. Sample costs to produce rice. UC Cooperative Extension and Department of Agricultural and Resource Economics, RI-SV-01. www.plantsciences.ucdavis.edu/ uccerice/STATS/2001Rice.pdf. 